International Journal of Engineering \& Technology, $7(4.33)(2018)$ 153-156
International Journal of Engineering \& Technology
SPC
Website: www.sciencepubco.com/index.php/IJET
Research paper

\title{
Tracer Study of Building Engineering Education Graduates for Academic Year 2012-2015
}

\author{
Fitri Ramadhanti ${ }^{1 *}$, Satoto E. Nayono ${ }^{2}$, Asnul Dahar Minghat ${ }^{3}$, Fahmi Rizal $^{4}$ \\ ${ }^{1}$ Vocational and Technology Education, Postgraduate Program, Yogyakarta State University, Indonesia \\ ${ }^{2}$ Faculty of Engineering, Yogyakarta State University, Indonesia \\ ${ }^{3}$ Razak Faculty of Technology and Informatics, University Teknologi Malaysia, Malaysia \\ ${ }^{4}$ Faculty of Engineering, Padang State University, Indonesia \\ *Corresponding author E-mail: ramadhanti553@gmail.com
}

\begin{abstract}
This study originated from the absence of career data from graduates of the Building Engineering Education Study Program at Padang State University. The purpose of this tracer study is to obtain data on graduate work, specifically the objectives to be achieved are knowing the career choices of graduates of Building Engineering Education study programs. Data collection techniques using a Guttman scale questionnaire and data analysis techniques using descriptive analysis. The population in this study were students graduating from the S-1 Building Engineering Education study program from graduates in 2012 to 2015 . The sampling technique used was purposive sampling with a sample of 88 respondents. Data found that 88 graduates who had worked were $96.59 \%$ with a description of $30.68 \%$ working in the education sector, $52.68 \%$ working in construction services and $13.64 \%$ working in other fields. The biggest factor influencing career choices in education is the internal factor with sub indicators of work characteristics $88.89 \%$. Factors influencing career choices in construction services are external factors with $93.48 \%$ sub indicator of communication and financial awards (salary) $83.33 \%$. Factors that influence career choices in other fields are external factors with sub indicators of the graduate process getting a job $12.50 \%$.
\end{abstract}

Keywords: career choices; influencing factors; tracer study.

\section{Introduction}

Education plays a very important role to form a whole human being because education is a vehicle to increase the growth and survival of a person, state and nation and develop the quality of human resources. Realizing that the importance of education is so important, it will encourage someone to continue their education to a higher level. This desire may be caused by several reasons such as the desire to add insight, and knowledge, the desire to get a certain degree, see the needs of the workforce, the desire to be professional in a field. So they hope to get decent work in the future.

One educational institution in West Sumatra that opened the education study program pathway, Padang State University. Padang State University (UNP) based its education program on Pancasila and the 1945 Constitution as well as the outlines of the country's direction. One of UNP's missions is to provide quality education in the fields of education, science, technology, sports and art based on devotion to God Almighty. The Faculty of Engineering is one of 8 faculties at UNP, one of which is a Building Engineering Education with a bachelor's degree.

The Building Engineering Education Study Program has a vision "To be a study program producing candidates for professional educators who excel in the field of Building Engineering Education in 2020 and devote themselves to God Almighty" [1]. Based on this vision, the graduates expected in the Building Engineering Education Study Program are to become professional teaching staff in the field of building engineering education. Based on traceable data, many students graduated from the Building Engineering Education Study Program who had a career in the field or in the field of construction services. The following is the career data of the students graduated from the Building Engineering Education Study Program that are tracked.

Table 1: Career Data Graduates of Building engineering education from 2012-2015

\begin{tabular}{|c|c|c|c|c|}
\hline No. & Career Name & $\begin{array}{c}\text { Number of } \\
\text { Tracked } \\
\text { Graduates }\end{array}$ & $\begin{array}{c}\text { Percentage } \\
(\%)\end{array}$ & $\begin{array}{c}\text { Number of } \\
\text { Graduates } \\
(2012- \\
\text { 2015) }\end{array}$ \\
\hline 1 & $\begin{array}{c}\text { Field of } \\
\text { Education }\end{array}$ & 10 & 15,9 & \multirow{2}{*}{187} \\
\cline { 1 - 3 } 2 & $\begin{array}{c}\text { Construction } \\
\text { Service }\end{array}$ & 32 & 50,8 & \multirow{2}{*}{187,3} \\
\hline 3 & Other Fields & 21 & 33,3 & \\
\hline & Total & 63 & 100 & \\
\hline
\end{tabular}

Based on Table 1, it is known that as many as 63 people from the representative of graduates, amounting to 187 people, showed a career imbalance of graduates with the vision of the Building Engineering Education Study Program. This is not only influenced by the interest of graduate students in entering the world of education, but there are many factors that influence graduates of S1 Building Engineering Education Study Program in their career selection. These factors can be grouped into two main groups, namely internal factors and external factors. 
Occupational exploration influences college student career decision making and ability to acclimatize in different environments. An interaction was observed between selfexploration, optimism, dynamism, making. Results revealed that students with high occupational exploration have high levels of decision making for employability [2]. There are significant relationships between self-knowledge and career decision-making as well as between occupational exploration and career decisionmaking [3]. Our young people prefer the security of tenure in employment through the employment route, at least short after graduation today, who are seeking employment to compete for jobs, are not growing at the same pace with the demand from the industry for their services [4].

The research findings will serve as a basis for researchers to improve, update or improve the building engineering education curriculum to make it more responsive to industry needs.

\section{Literature Review}

\subsection{Career Choices}

A career is an evolving sequence of work activities and positions that individuals experience over time as well as the associated attitudes, knowledge and skills they develop throughout their life [5]. Careers are a series of attitudes and behaviors that relate to work experience and activities during a person's life span and a continuous series of work activities [6].

From some of the opinions above it can be concluded that a career is a job position that has the rights and obligations to produce goods or services and benefit economically that requires skills, interests and values that allow it to continue to grow and bring inner satisfaction to someone and also a lifestyle live it.

Choice of career is a lifelong process of decision-making in which the students seek to find the optimal link between their careers preparation, goals and the realities of the world of work [7]. The choice of career of the most difficult decisions student are confronted with. Individuals with career maturity actively design career, look for information about career choices, talk to the parties concerned (counselors, family and others) about planning his career, take part in outdoor activities or work part-time that would help him to explore career, attend related courses and obtain additional information that could add value to his future career [8]. Career choice is a job selection process that is influenced by psychological, sociological, cultural, geographical factors, education, physical economy, and open opportunities that together form a person's position, where someone has gained a number of beliefs, the value of needs, abilities, interest skills, personality traits, understanding, and knowledge that are all related to the position he holds [9]. "Choice" means "choosing or separating from two or more things that are preferred" [10]. Based on the opinions of the experts above, it can be concluded that career choices are career determinations that affect one's position. Parental authority has a positive relationship with career decisionmaking difficulties whereas personality indicates a negative relationship with career decision-making difficulties [11]. There is a relationship between career decision-making and occupational exploration and students who have high career decision making abilities have high occupational exploration [12].

\subsection{Factor Affecting Career Choices}

Among the factors affecting career choices of adolescents, intrinsic factors (e.g., gender, personality factors, abilities, expectations, perceptions, and motivational influences) and extrinsic factors (e.g., SES and cultural background, school curricula, teachers' attitudes and support for school subjects, parental attitudes and values, and societal perception towards occupations) seem to be noteworthy [13]. Communication skill is considered the foremost competency learned in college that found very useful to their job placement [14]. The abilities identified by the respondents useful in their job include: the skills on entrepreneurial, human resource, communication, critical thinking, information technology and problem-solving [15].

There are several career choice factors that play a role and support it. The factors that influence and support career selection are internal and external factors including: (1) Internal factors are factors that originate from oneself which consist of learning achievement, ideals, interests, hobbies and traits. (2) External factors, are factors that come from outside the self (environment) which consists of the family environment, school environment, peer environment and so on [16]. Other studies found that, Malaysian graduates normally were qualified in their area of studies, but they lacked self-confidence and lack skills of prepare for job-search [17], and their main drawbacks are lack of positive attitude, confidence, and prepare for job search [18]. Career choices were mostly affected by intrinsic factors (i.e., selfaspirations), whereas interpersonal factors (i.e., significant others' expectations) were least influential. Findings were discussed in light of dynamic and changing cultural characteristics of the Turkish society [19].

\subsection{Tracer Study}

A tracer study of past graduates of any institution, is always considered important. This is because it enables the graduating institution to monitor its graduates with regards to their effectiveness in the tasks assigned to them and also to find out if they meet the expectations of their employers [20]. Graduate tracer studies are one form of empirical study that can appropriately provide valuable information for evaluating the results of the education and training of a specific institution of higher education [21]. The importance of the tracer study is as follows: "By conducting a survey on the cohort of graduates from a specific institution, profession, discipline, level of education, their employment characteristics, competencies and skills development, and have a comparative analysis, the information gained from these can be used by the graduate's alma mater and other education stakeholders for curriculum development and other emerging reforms [22]. Tracer study intended to assess the relevance of the curriculum, knowledge and skills acquired by the graduates for their employment; identify the personal and professional characteristics and job placement of the Computer Engineering graduates and the school-related factors associated with their employment [23]. The Tracer Study of Higher Education graduates is one of the alternatives needed to obtain answers to the needs of the work / industry world [24]. Tracer study is part of the identification process to see the success of the graduates in terms of the relevance aspects of the basic competencies of graduates desired by graduate users. Thus the Study of tracking of Higher Education graduates is "a study that is included in the category of descriptive research that seeks to find what is done by higher education to support the world of work in the context of sustainable economic development". Therefore, the Tracking Study of university graduates is a research study focused on exploring and obtaining information from higher education alumnus.

\subsection{Building Engineering Education Study Program}

Building Engineering Education Study Program, is one of the study programs from the Department of Civil Engineering, Faculty of Engineering, Padang State University. The Building Engineering Education Study Program is a study program to produce a Bachelor of Building Engineering Education with a Bachelor of Education (S.Pd) degree which has the main competency as a beginner teacher in the Technology and Engineering Vocational School in Building Engineering expertise.

Referring to the description of the vision, mission, goals and profile of graduates that have been attached, it can be concluded that graduates of the Department of Building Engineering Study Program are expected to become professional educators and 
educators in the field of engineering, especially buildings and civilians, both in formal environments such as schools. Vocational Middle School (SMK) or in a non-formal environment such as construction services.

\section{Methodology}

This type of research is descriptive research. This research was carried out using the help of the internet, namely: blog, e-mail, Facebook, shipping services and face-to-face contact with affordable respondents.

The population in this study were graduates of the Building Engineering Education study program which was declared graduated from 2012 to 2015 . The population was 187 people. The sampling technique was taken through the Purposive Sampling method. Purposive sampling is a technique for determining samples with certain considerations [25].

The data used in the study uses primary data and secondary data. Primary data is direct data from respondents taken through questionnaires / questionnaires. Secondary data is the initial data in the form of data from the Building Engineering Education Study Program graduates from 2012 to 2015 obtained from the UPT. UNP Puskom.

Instrument testing is conducted to find out and select instrument items that meet the requirements to be used as a data collection tool. From the data of the instrument trial results, an analysis was conducted to determine the validity and reliability. The instrument validity is done using the Product Moment formula using the help of the Microsoft Office Excel program. For instrument reliability, the test results show that the instrument is reliable with a Cronbach's Alpha value of 0.942 (very high)

\section{Results and Discussion}

The results of research from career choice indicators for graduates of Building Engineering Education Study Program can be seen as follows:

Table 2: General information about the year of entry of respondents to UNP

\begin{tabular}{|c|c|c|}
\hline Year of Entry & Frequency & Percent (\%) \\
\hline$\leq 2007$ & 17 & 19,32 \\
\hline $2008-2009$ & 51 & 57,95 \\
\hline $2010-2012$ & 20 & 22,73 \\
\hline Total & 88 & 100 \\
\hline
\end{tabular}

Table 3: General information about the year of graduation of respondents from UNP

\begin{tabular}{|c|c|c|}
\hline Graduation Year & Number of (People) & Percent (\%) \\
\hline 2012 & 12 & $13,64 \%$ \\
\hline 2013 & 17 & $19,32 \%$ \\
\hline 2014 & 30 & $34,09 \%$ \\
\hline 2015 & 29 & $32,95 \%$ \\
\hline Total & 88 & $100 \%$ \\
\hline
\end{tabular}

\subsection{Factor Affecting Career Choices for Graduates in Education}

Data obtained from respondents totaling 88 people obtained information that 27 people or $30.68 \%$ worked in the field of education. The results of the analysis show that a very high factor in influencing the career choice of Building Engineering Education graduates working in the field of education is the Internal Factor, which can be seen from the sub-indicators of Nature as much as $88.89 \%$ which are categorized as very high. Building Engineering Education Study Program graduates get jobs of less than 6 months as many as 21 people and more than 6 months as many as 6 people. Salaries earned by graduates are small or equal to 2 Million Rupiah as many as 8 people and salaries earned 2 Million Rupiah up to 4 Million Rupiah as many as 19 people.

\subsection{Factors Affecting Career Choices of Graduates in Construction Services}

The results of the analysis show that of the 88 respondent as many as 46 people or $52.27 \%$ work in the field of construction services. A very high factor in influencing the career choice of Building Engineering Education graduates working in the field of construction services is the External Factor, which can be seen from the communication sub indicator as much as $93.48 \%$ which is categorized as very high. Building Engineering Education Study Program graduates get jobs less than 6 months as many as 36 people and more than 6 months as many as 10 people. Salaries earned by graduates are small or equal to 2 Million Rupiah as many as 4 people, salary obtained 2 Million Rupiah up to 4 Million Rupiah as many as 32 people and salary obtained is greater than 4 Million Rupiah as many as 10 people The analysis shows that of 88 respondents 46 people or $52.27 \%$ work in construction services.

A very high factor in influencing the career choice of Building Engineering Education graduates working in the field of construction services is the External Factor, which can be seen from the communication sub indicator as much as $93.48 \%$ which is categorized as very high. Building Engineering Education Study Program graduates get jobs less than 6 months as many as 36 people and more than 6 months as many as 10 people. Salaries earned by graduates are small or equal to 2 Million Rupiah as many as 4 people, salaries earned 2 Million Rupiah up to 4 Million Rupiah as many as 32 people and salaries earned greater than 4 Million Rupiah as many as 10 people.

\subsection{Factor Affecting Career Choices in Other Fields}

The results of data analysis showed that out of 88 respondents, 12 people or $13.64 \%$ worked outside the field of education and construction services. A very high factor in influencing the career choice of Building Engineering Education graduates working in other fields is the External Factor, where it is seen from the sub indicator of Communication as much as $83,33 \%$ which is categorized as very high Building Engineering Education Study Program graduates get jobs less than 6 months as many as 9 people and more than 6 months as many as 3 people. Salaries earned by graduates are small or equal to 2 Million Rupiah as many as 4 people, salaries earned 2 Million Rupiah up to 4 Million Rupiah as many as 6 people and salaries earned greater than 4 Million Rupiah as many as 2 people.

\section{Conclusion}

Most of the Building Engineering Education graduates from 20122015 got jobs with a bachelor's degree with the most types of jobs in the field of construction services. Communication is the main factor influencing graduates in their career choices. Communication skills are considered to be the leading competencies learned in college which are very useful for those graduates in work.

The results of the research can be conveyed to the suggestion that the chairman of the civil engineering department is expected to reevaluate the curriculum used in the S1 Building Engineering Education Study Program and is expected for the Civil Engineering Department to be able to guide or give feedback to students about the future career choice come. To the Chairperson of the Building Engineering Education Study Program, it is hoped that he can evaluate the data collection or tracking of graduates which will be useful for evaluating the curriculum used. To students of the Building Engineering Education Study Program, it is suggested that they can equip themselves with various skills or at least have a special skill that is useful in determining career choices from the beginning of becoming a student, because of the high level of competition among job seekers. 


\section{References}

[1] Padang State University. (2015). Buku pedoman akademik FT UNP. Universitas Negeri Padang.

[2] Hmieleski, K. M., \& Baron, R. A. (2008). When does entrepreneurial self-efficacy enhance versus reduce firm performance? Strategic Entrepreneurship Journal, 2(1), 57-72.

[3] Abdullah, N., Hussin, N., Shonubi, O. A., Ghazali, S. R., \& Talib, M. A. (2018). Career decision-making competence, selfknowledge, and occupational exploration: A model for university students. Journal of Technical Education and Training, 10(1), 7181.

[4] De Ocampo, M. (2009). Graduate tracer study: Employability of recent graduates of University of San Carlos-College of Commerce. Studies in International Cultures, 5(1), 1-49.

[5] El-Sabaa, S. (2001). The skills and career path of an effective project manager. International Journal of Project Management, 19(1), 1-7.

[6] Gibson, J. L, Ivancevich, J. M, Donnelly, \& Konopaske, J. H (1995). Oganizations: Behavior, structure, process. McGraw-Hill.

[7] Odo, M. I. (2015). Sustaining occupational information for career choice and development in students of technical colleges in Enugu State, Nigeria. Journal of Technical Education and Training, 7(1), $1-9$

[8] Amla, S., Zuria, M., \& Salleh, A. (2009). Bimbingan dan kaunseling sekolah. Universiti Kebangsaan Malaysia Press.

[9] Winkel, W. S. (1997). Bimbingan dan konseling di institusi pendidikan. Grasindo.

[10] Sahala, F. I. (2014). Survey tentang pilihan karir mahasiswa Fakultas Teknik Universitas Negeri Surabaya. Jurnal BK UNESA, 4(3), 667-674

[11] Chen, L. S., \& Liew, S. A. (2015). Factors influencing career decision-making difficulties among graduating students from Malaysian private higher educational institutions. Proceedings of the 8th Asia-Pacific Business Research Conference, pp. 1-17.

[12] Chuang, N. K, \& Dellmann-Jenkins, M. (2010). Career decision making and intention: A study of hospitality undergraduate students. Journal of Hospitality and Tourism Research, 34(4), 512 530 .

[13] Korkmaz, H. (2015). Factors influencing students' career chooses in science and technology: Implications for high school science curricula. Procedia-Social and Behavioral Sciences, 197, 966-972.

[14] Dotong, C. I., Chavez, N. H., Camello, N. C., De Castro, E. L., Prenda, M. T. B., \& Laguador, J. M. (2016). Tracer study of engineering graduates of one higher education institution in the Philippines for academic year 2009-2012. European Journal of Engineering and Technology, 4(4), 26-39.

[15] Caminade, L. M., Flores, L. P., \& Sagarino, E. V. (2018). A tracer study on the employability status of the university of the immaculate conception accountancy graduates: Implication of their academic training. International Journal of Education Research for Higher Learning, 22(1), xxx.

[16] Widola, R. (2011). Faktor-faktor pendukung arah pilihan karir siswa SMA Negeri 7 Sijunjung. Skripsi, BK FIP UNP.

[17] Zuraidah, O. (2008). The ideal graduate. GRADUAN. Careers and employment for Malaysian fresh graduates 2008. BIZ Connexion Sdn. Bhd.

[18] Lazaroo, S. (2008). Carve your niche at Naza. GRADUAN. Careers and employment for Malaysian fresh graduates 2008. BIZ Connexion Sdn. Bhd.

[19] Aycan, Z., \& Fikret-Pasa, S. (2003). Career choices, job selection criteria, and leadership preferences in a transitional nation: The case of Turkey. Journal of Career Development, 30(2), 129-144.

[20] Aina, L. O., \& Moahi, K. (1999). Tracer study of the Botswana library school graduates. Education for information, 17(3), 215 244.

[21] Schomburg, H. (2003). Handbook for graduate tracer studies Deutsche Gesellschaft für Technische Zusammenarbeit (GTZ) GmbH. http://www.uni-kassel. de/wz1/proj/edwork/handbook.ghk.

[22] Gines, A. C. (2014). Tracer study of PNU graduates. American International Journal of Contemporary Research, 4(3), 81-98.

[23] Laguador, J. M., \& Dotong, C. I. (2013). Tracer study of BS computer engineering graduates of Lyceum of the Philippines University. International Journal of Management, IT and Engineering, 3(8), 387-401.

[24] Sayuti, S. (2012). Profil lulusan (tracer study) jurusan kepelatihan program studi pendidikan kepelatihan olahraga Fakultas Ilmu Keolahragaan Universitas Negeri Padang. Technical report, Universitas Negeri Padang.
[25] Sugiyono. (2017). Metode penelitian pendidikan pendekatan kuantitatif kualitatif, dan RnD. Alfabeta. 